\title{
Stimulating the Formation of the Physician-Scientist; Scientific Exposure during the Medical Course in Brazil
}

\author{
Vitor Rosa Ramos de Mendonça \& Manoel Barral-Netto \\ Faculdade de Medicina, Universidade Federal da Bahia and Centro de Pesquisas Gonçalo Moniz, \\ Fundação Oswaldo Cruz, Salvador, Bahia, Brazil
}

\begin{abstract}
Despite major advances in medical research, there is a decline in the number of physician-scientists. It is necessary to stimulate the involvement of MDs in the scientific endeavor. Brazil has a national program which stimulates the participation of undergraduate students, including medical students, in research projects as a regular academic activity. Herewith we analyze the introductory scientific program and the involvement of MDs in research in Brazil. The program to promote early scientific exposure during the undergraduate or medical course has the objective of recognizing students with aptitude for scientific research. Brazilian research groups in the area of medicine show a continuous increase, and the health sciences represent a sizable part of graduate students who receive scientific initiation fellowships. An important part of students who participated in introductory scientific programs continued in scientific activities in graduate programs. This finding supports the importance of basic scientific research in stimulating students to follow a scientific career.
\end{abstract}

In Brazil approximately $2 \%$ of the population 15 years old or older has a postgraduate degree and Brazil produces approximately $2 \%$ of the internationally-indexed scientific papers worldwide.1,2 In 2008, Brazil's world ranking in production of scientific articles was $13^{\text {th }}(30,415$ manuscripts) in the Institute for Scientific Information (ISI) database. ${ }^{3}$ The Thomson Reuters' report on Brazil's situation in science indicates that the country doubled its output in the ten years prior to 2007 , and that its growth exceeds those of most other economies. 4 Brazil invested 1.09\% of its Gross Domestic Product (GDP) in scientific research, an average investment of US\$ 121.4 per capita and US\$ 172,732 per researcher, according to data from 2008.5 For comparison, USA in the same year published 340.638 studies and invested $2.77 \%$ of GDP on scientific research, representing US $\$ 1307.2$ per capita and US $\$ 243,900$ per investigator.3,5

As a country's development is linked to scientific activity, the country needs to increase its post graduate population to enhance its scientific productivity. To stimulate the expansion of a country's scientific base it is necessary to stimulate an interest in research early in the students' life. The country's technological development is closely linked to the manner and extent to which young people are encouraged to do research. It is in this context that there rises the idea of introductory scientific programs (ISP). ${ }^{6}$

\begin{abstract}
Physician-scientists are essential to ongoing biomedical advances.7 However, the number of physician-scientists continues to decrease. ${ }^{8}$ Progressively fewer physicians are interested in a scientific career because of the low remuneration, long training and preparation, as well as low government investment in this issue. In this study, we comment on introductory scientific programs with emphasis on the Brazilian national program, present data on the current situation of medical research and the involvement of MDs in research in Brazil.
\end{abstract}


Advantages and goals of

\section{introductory scientific programs}

ISPs aim to introduce undergraduate students into the realm of scientific research. One goal of these programs is to encourage new potential talents, through participation in research projects supervised by qualified researchers, preparing them for entry into graduate studies. Furthermore, the introductory scientific programs aim to contribute to reducing the average time for completion of PhDs, accelerating the formation and scientific expertise of students. ${ }^{9}$ Pursuit of an academic career in educational institutions in Brazil requires proper scientific training and even in the case of MDs the need for obtaining a $\mathrm{PhD}$. The interest in teaching has been confirmed by the intense growth of students in graduate programs and in those who affirm that a future academic career is a major goal for them. ${ }^{10}$ Because of intense competition, those with greater scientific training and research knowledge have better opportunities.

ISPs may have impact the professional career, as it enables a greater understanding of the labor market by allowing the interaction between the scientific world and practical activities of the profession.11 ISP-exposed individuals develop a cooperative attitude through teamwork, by developing a systematic vision of interdisciplinary and cooperative work and developing activities related to planning, implementing, interpreting and communication of scientific research and its results. ${ }^{12,13}$ Additionally, they are more interested in their professional formation and present lower dropout rates in their undergraduate courses. ${ }^{14}$

\section{Introductory scientific programs in Brazil}

The Brazilian National Council for Scientific and Technological Development (CNPq) finances ISP through the granting of annual fellowships to encourage postgraduate research, an effort followed by several State Agencies throughout Brazil15. In $1988 \mathrm{CNPq}$ created the Institutional Program of Introductory Scientific Fellowships - PIBIC. This program grants a quota of scientific fellowships to educational institutions which are directly responsible for managing the fellowships and their evaluation. The program reaches $78 \%$ of public educational institutions and $71 \%$ of privates ones countrywide $^{16}$. An annual meeting where fellows present their scientific production is mandatory. Student performance is evaluated by a committee which includes external observers. ${ }^{15}$

The number of introductory scientific fellowships distributed by CNPq has grown since 1976. In 1976, 845 students received fellowships from CNPq; in 1997 it reached 18,856 students, and this figure continues to increase. In 2009, 24,043 undergraduate students received PIBIC fellowships and $3,485(14.49 \%)$ of them were in the health sciences (Figure 1). In the same year, CNPq invested approximately U\$ 420 million in research fellowships, and scientific initiation fellowships accounted for $10.12 \%$ of these expenses. ${ }^{17}$ In recent years biological sciences represented the area with the largest number of fellows (Table 1 ). ${ }^{17}$ Of note is the fact that in the last ten years female fellows outnumbered male fellows, and in 2009 the former group accounted for $56 \%$ of all scientific initiation fellowships granted.

\begin{tabular}{|c|c|c|c|}
\hline \multirow{2}{*}{ Area / Modality } & \multicolumn{3}{|c|}{ Number of fellowships-year } \\
\hline & 2001 & 2005 & 2009 \\
\hline Agrarian Sciences & 3.143 & 2.798 & $3 \cdot 325$ \\
\hline Biological Sciences & 3.100 & 3.411 & 3.996 \\
\hline Health Sciences & 2.423 & 2.512 & 3.485 \\
\hline Earth and Exact Sciences & 2.357 & 2.936 & $3 \cdot 550$ \\
\hline Humanities Science & 2.768 & 2.860 & 3.457 \\
\hline Applied Social Sciences & 1.396 & 1.425 & 1.639 \\
\hline Engineering & 2.682 & 2.896 & 3.170 \\
\hline Linguistics, Literature and Arts & 854 & 905 & 1.094 \\
\hline Multidisciplinary / Other / not reported & 55 & 169 & 328 \\
\hline Total & 18.778 & 19.912 & 24.043 \\
\hline
\end{tabular}

Table 1: Number of introductory scientific fellowships distributed by PIBIC according to area/modality of science between 2001 and 2009. Source: CNPq (National Council for Scientific and Technological Development). 


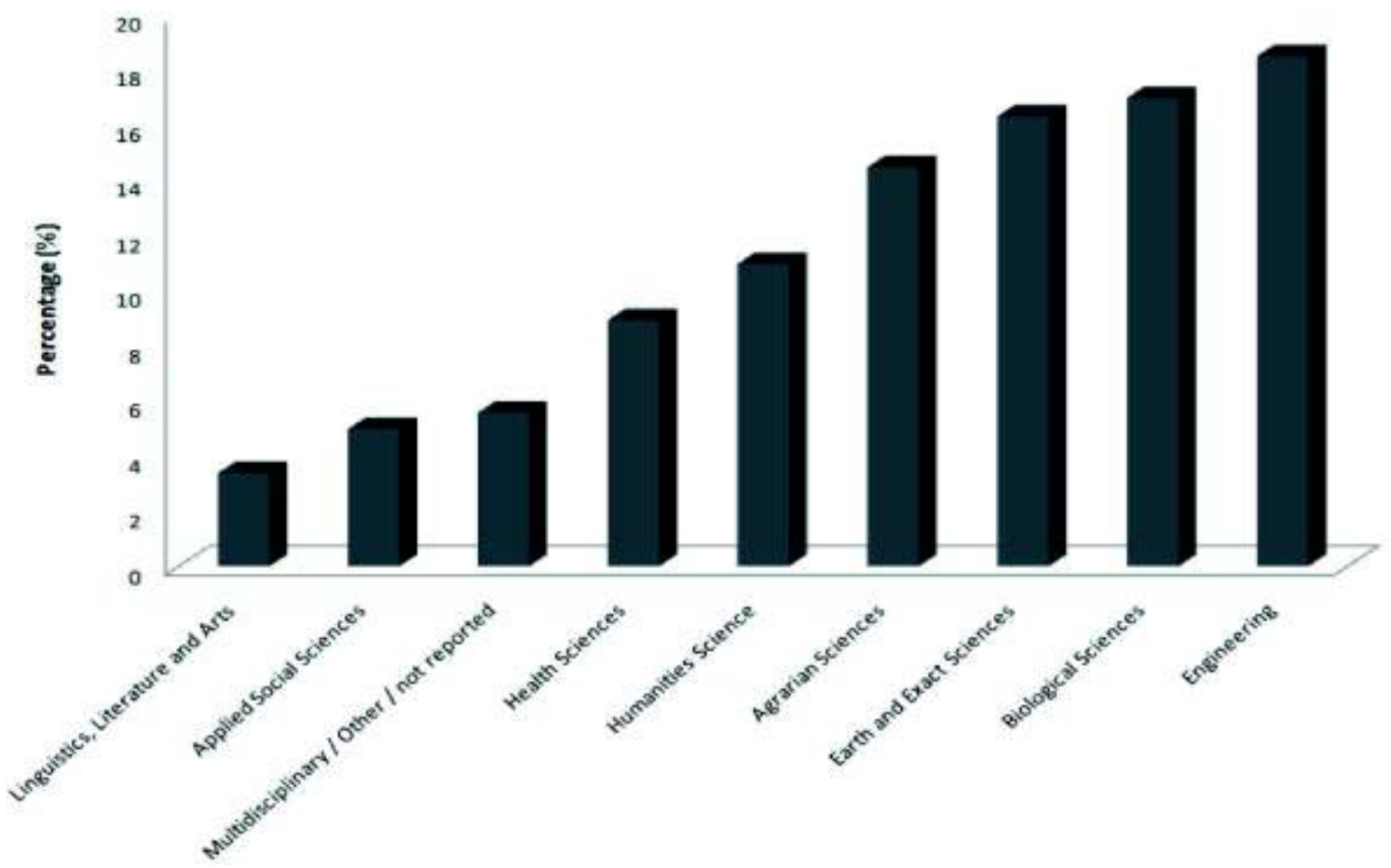

Figure 1: Percentage of CNPq investments in fellowships according to area of science in 2009. CNPq investments are subdivided according to area of science. In this figure each column corresponds to an area of science and its percentage of fellowships from the total supported by the CNPq in 2009. Source: CNPq (National Council for Scientific and Technological Development).

According to an interesting study conducted by CNPq, about $26 \%$ of students who participated in ISP in the period between 1994 to 2006 continued in scientific activities in graduate programs in the period 1996-2008.17 The chance for enrolling in a graduate program is approximately six times higher with former PIBIC fellows compared to individuals without ISP experience. This finding confirms the importance of ISP in stimulating the students to follow a career based on scientific expertise. Additionally, experience in ISP during undergraduate study relates to a reduced time for completion of a graduate program compared to students who have not had this experience during their undergraduate work (Table 2). Additionally, $44 \%$ of the graduates from public educational institutions, and about 50\% of those from private institutions, consider that introductory scientific projects had contributed to their education. On the other hand, $20 \%$ of graduates said that the ISP had little or no impact in their development. ${ }^{16}$

\section{Introductory scientific programs in medicine and the physician- scientists}

According to the Brazilian National Curriculum Guidelines for Medicine Graduation, educational institutions which offer medical courses need to develop complementary activities in addition to a minimum curriculum, and among such offerings is the ISP. ${ }^{18}$ About $84 \%$ of medical students advocate mandatory ISP at graduation, while only $7 \%$ of them indicate no interest in research. ${ }^{19}$ Real numbers of participation show a slightly different picture. In a study of 413 medical students from six different schools, it was found that $68 \%$ of them participated in the ISP during undergraduate study, while $28 \%$ went through the entire course without enrolling in this kind of activity.19 Participation in ISP during undergraduate study differs among professional careers. Medical students participate more in introductory scientific programs when compared to law students (30.8\% versus 2.9\%). ${ }^{20}$ It seems that the medical course encourages students to participate in scientific activities. The same study evidenced that ISP influenced development in the understanding of theoretical and practical scientific concepts over time. ${ }^{20}$ 


\begin{tabular}{ccc}
\hline $\begin{array}{l}\text { Age (years) at } \\
\text { end of graduate } \\
\text { studies }\end{array}$ & $\begin{array}{c}\text { Former PIBIC } \\
\text { fellows } \\
\text { during } \\
\text { undergaduation (\%) }\end{array}$ & $\begin{array}{c}\text { Non fellows during } \\
\text { undergraduation } \\
\text { (\%) }\end{array}$ \\
\hline Up to 24 & 8.46 & 2.45 \\
{$[25,27]$} & 49.55 & 20.39 \\
{$[28,30]$} & 26.27 & 19.67 \\
Above 30 & 15.72 & 57.49 \\
\hline
\end{tabular}

Table 2: Comparison between the ages of graduates students who had or did not have scientific initiation fellowships in undergraduate courses, between 1996 and 2008. PIBIC: Institutional Program of Introductory Scientific Fellowships. Source: CNPq (National Council for Scientific and Technological Development).

\begin{tabular}{cccc}
\hline Year & MD & $\begin{array}{c}\text { MD, } \\
\text { PhD }\end{array}$ & MD, PhD as \% of total \\
\hline 2000 & 2,234 & 1,481 & 44.76 \\
2008 & 4,687 & 3,372 & 46.26 \\
\hline Increase (\%) & 209.8 & 227.7 & \\
\hline
\end{tabular}

Table 3: Number of $M D$ and $M D-P h D$ Brazilian scientists funded by CNPq. CNPq: National Council for Scientific and Technological Development. Percentage of total refers to the total of investigators holding doctoral degrees (MD, MD-PhD, $P h D)$ and listed in medical research groups.

There is no large survey about the significance of ISP in medical courses. Several institutions have published their experiences of implementing such programs on their sites. ${ }^{6}$ These publications point out the difficulty of installing a consistent project of ISP, which may be the reason why only a small number of medical courses have a well established program of Scientific Initiation. ${ }^{21}$

The scientific advances in medicine progressively increase over time and physician-scientists are progressively less frequent. ${ }^{22}$ The number of physician-scientists is not following the increase of scientific and research needs in the medical area, hampering scientific advances. Research groups in the area of medicine increased from 737 in 2000 to 1355 research groups funded by CNPq in 2008, an increase of $83.85 \%$ in 8 years. ${ }^{22}$ In 2000,1481 (44.76\% of total) of medical researchers were PhDs. Approximately $46.26 \%$ of the physician-scientists $(\mathrm{n}=3372)$ were $\mathrm{PhD}$ in 2008. Between 2000 and 2008 the number of physician-scientists increased 209.8\% for MD medical researchers and $227.7 \%$ for those with the MD, PhD (Table 3).

\section{Conclusions}

Scientific production is closely related to the social and economic development of a country and Brazil has a growing but still small production of scientific articles. Additionally, if the advances of medicine are not followed by the number of physicianscientists and the future of medical research may be compromised. Therefore, specific policies should be made in order to stimulate medical students to follow a scientific career. Inclusion of the student in scientific research is crucial to the formation of potential scientists and introductory scientific programs are effective mechanisms for this reason. The Brazilian introductory scientific program is making progress in offering research experience to undergraduates, including medical students. It is also of note the increase in the number of physicians (with $\mathrm{MD}$ or $\mathrm{MD} / \mathrm{PhD}$ degrees) active in medical research in Brazil in the period from 2000 to 2008. It is not possible to establish a link between these two aspects, as many other factors are involved, but relationship between participating in scientific initiation programs and participation in medical research afterwards seems promising in the Brazilian context.

\section{Acknowledgments}

Mr. Claudio Valério, from CNPq, kindly provided the data used in Table 3. We are indebted to Drs. Allen Cheever and Robert Verhine for critically reading the manuscript.

\section{Notes on Contributors}

VITOR ROSA RAMOS DE MENDONÇA is a Medical Student at Universidade Federal da Bahia, Bahia, Brazil.

MANOEL BARRAL-NETTO, PhD MD, is Professor of Pathology at Universidade Federal da Bahia, Bahia, Brazil.

\section{Keywords}

Physician-Scientist, Medical Education, Scientific Initiation 


\section{References}

1. National Science Board. Science and Engineering Indicators: 2010. http://www.nsf. gov/statistics/seind10/ [Accessed November 14, 2010]

2. Thomson Reuters Web of Knowledge. http://wokinfo.com [Accessed November 14, 2010]

3. Palis, J. Um olhar sobre a ciência Brasileira e sua presença internacional. www.abc.org.br/ IMG/pdf/doc-195.pdf [Accessed November 17, 2010]

4. Adams, J., and King, C. Global Research Report Brazil Research and collaboration in the new geography of science. Thomson Reuters: 2009.

5. Organisation for Economic Co-operation and Development, Main Science and Technology Indicators 2009/2. http://www.oecd.org/ document/26/0,3343,en $264933703 \quad 190108$

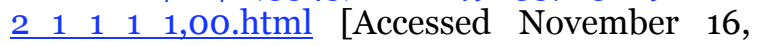
2010]

6. Tenório, M.P., and Beraldi, G. Iniciação científica no Brasil e nos cursos de medicina. Rev Assoc Med Bras. 2010; 56 (4):375-93.

7. Dyrbye, L.N., Lindor, K.D., LaRusso, N.F., and Cook, D.A. Research productivity of graduates from 3 physician-scientist training programs. The American Journal of Medicine. 2008; 121 (12):1107-1113.

8. Rosenberg, L. Physician-scientists-endangered and essential. Science. 1999; 283 (5400):331332.

9. Neves, R.M.C. Learning from scientific initiation or laboratory pedagogy. História, Ciências, Saúde - Manguinhos. 2001; VII (3):71-97.

10. Louzada, R.C.R., and Filho, J.F.S.Graduate studies and work: a study on the plans and expectations of Brazilian doctoral candidates. História, Ciências, Saúde - Manguinhos. 2005; 12(2):265-82

11. Erdmann, A.L., Leite, J.L., Nascimento, K.C., and Lanzoni, G.M.M. Viewing the meaning of the scientific starting from the graduating nursing student. Esc Anna Nery Rev Enferm. 2010; 14 (1):26-32.

12. Radünz, V. and Erdmann, A.L. Organização de um sistema de compartilhamento e intercâmbio de produção de conhecimento entre a enfermagem da região sul do Brasil. Texto\&Contexto Enferm. 1996; 5 (2):258-70.

13. Filipecki, A., Barros, S.S., and Elia, M.F. Researchers-mentors' views about a high school students scientific training. Ciência E Educação. 2006; 12 (2):199-217.
14. Bôas, G.K.V. Currículo, iniciação cientifica e evasão de estudantes de ciências sociais. Tempo Social - USP. 2003; 45-62.

15. Massi, L., and Queiroz, S.L. Estudos sobre iniciação científica no Brasil: uma revisão. Cadernos de Pesquis. 2010; 40 (139):173-197.

16. Ministério da Educação. Instituto Nacional de Pesquisas e Estudos Educacionais Anísio Teixeira - Informativo ano $3 \mathrm{n} .98$ - 20 jul 2005. http://www.inep.gov.br/informativo/informati vo98.htm [Accessed November 2, 2010].

17. Conselho Nacional de Desenvolvimento Científico e Tecnológico. Estatísticas. http://www.cnpq.br/estatisticas/index.htm [Accessed October 1, 2010].

18. Ministério da Educação. Conselho Nacional de Educação. Resolução CNE/CES n. 4, de 7 de novembro de 2001. Institui Diretrizes Curriculares Nacionais do Curso de Graduação em Medicina. http://portal.mec.gov.br/cne/ arquivos/pdf/rces001 07.pdf [Accessed November 2, 2010].

19. Oliveira, N.A., Alves, L.A., and Luz, M.R. Iniciação científica na graduação: o que diz o estudante de medicina? Rev Bras Educ Med. 2008; 32 (3):309-14.

20. Reis-Filho, A., Andrade, B.B., Mendonca, V.R.R., and Barral-Netto, M. Research knowledge in undergraduate school in Brazil: a comparison between medical and law students. Einstein. 2010; 8:273-280.

21. Montes, G.S. Da implantação de uma disciplina de Iniciação Científica ao currículo nuclear na graduação em medicina na USP. Rev Bras Cardiol. 2000; 2 (2):70-7.

22. Koniaris, L.G., Cheung, M.C., Garrison, G., Awad, W.M., and Zimmers, T. PhD scientists completing medical school in two years: looking at the Miami PhD-to-MD program alumni twenty years later. Academic Medicine. 2010; 85 (4):687-691.

23. Ministério de Ciência e Tecnologia. Diretório dos Grupos de Pesquisa no Brasil. http://dgp.cnpq.br/censos/ [Accessed Nov ember 5,2010$]$ 